\title{
A HIVATÁSOS ÉS HIVATÁSOS PÁLYÁRA KÉSZÜLŐ LABDARÚGÓK FEJLESZTÉSÉNEK ÉS KARRIERTÁMOGATÁSÁNAK MAGYARORSZÁGI VIZSGÁLATA
}

A tanulmány célja a magyar hivatásos labdarúgók karriertámogatásának, valamint a sikeres professzionális karrier eléréshez szükséges képzések alkalmazásának vizsgálata. A nemzetközi hivatásos labdarúgásban mind a fiatal tehetségek kinevelése, mind a felnőtt játékosok szakmai és mentális képzése, mind pedig a játékosok karrier utáni civil életre történő felkészítése egyre nagyobb hangsúlyt kap a labdarúgó klubok és szövetségek munkájában. A kutatás alapját jelentő kérdőíves felmérést 200 magyarországi hivatásos játékos, illetve hivatásos pályára készülő utánpótlás labdarúgó töltötte ki. $A$ kutatás három témára fókuszált: tanulmányok, képzések és karriertámogatás. A tanulmány legfontosabb megállapításai szerint a hazai játékosok kevés egyéni képzést kapnak, klubjaik nem finanszírozzák a fejlődésüket segítő képzéseket és nem részesülnek megfelelő tehetséggondozásban sem. Továbbá, a játékosok a saját és a játékostársaik jövőbeli lehetőségeit is jobbnak ítélik meg a valós adatokhoz képest, ami az egyéni fejlesztésre vonatkozó motivációjukat is visszavetheti. Tisztában vannak vele, hogy extra képzésekre lenne szükségük, de erre nem áldoznak energiát, időt, valamint ebben a klubjuktól, illetve a szövetségtől sem kapnak megfelelő támogatást. A folyamatban lévő nemzetközi audit ajánlásainak beépítésével a játékosok fejlesztésének hatékonysága növelhető lenne.

Kulcsszavak: hivatásos labdarúgás, sportvállalat, hivatásos játékos, karriermenedzsment, humánerőforrás-fejlesztés

A hivatásos labdarúgó klubok teljesítményének egyik mérési lehetősége a tehetséges játékosok kinevelésének összehasonlítása, amelyet vizsgálhatunk az értékesített játékosok száma és ára alapján. A tehetséges játékosok a pályán nyújtott teljesítményükkel egyszerre járulhatnak hozzá a klub sportszakmai, valamint pénzügyi sikerességéhez (a sportesemények résztvevőjeként újabb fogyasztók generálásával), illetve értékesítésük esetén is jelentős bevételhez juttathatják nevelőklubjukat. A magyar labdarúgó klubok játékosok neveléséhez és értékesítéséhez kapcsolható hatékonysága nemcsak a legerösebb bajnokságokhoz képest, hanem a hasonló, közép-kelet-európai bajnokságokhoz képest is gyengének mondható (András - Havran, 2014, 2016). Ennek oka egyrészt kereshető az értékesítési kudarcokban, másrészt pedig az utánpótlás-nevelés hatékonyatlanságában, vagyis a játékosok képzésének, felkészítésének alacsony minőségében. Kutatásunk során arra kerestük a választ, hogyan értékelhető a hazai hivatásos labdarúgók fejlesztésének és karriermenedzsmentjének támogatása. Kutatásunk relevanciáját jelentik a gyengének mondható magyar eredmények a nemzetközi transzferpiacon (a klubok nem képesek a nemzetközi játékospiacon versenyképes játékosokat nevelni) és a nemzetközi hivatásos labdarúgó-bajnokságokban (klub és válogatott szinten egyaránt) (András - Havran, 2017). A probléma okának feltárását segítheti a játékosok képzésének, karriertámogatásának vizsgálata, amellyel célunk, hogy megismerjük a fiatal magyar hivatásos labdarúgók jövőképét, illetve tapasztalatot gyüjtsünk a karriermenedzsmentjükhöz kapcsolódóan, valamint arról, hogy hatékonyan szervezik-e a játékosok fejlesztéséhez kapcsolódó értékteremtő folyamataikat a klubok és a hozzájuk kapcsolódó akadémiák. Tanulmá- nyunkban nem sportszakmai okokat tárunk fel, hanem a háttérmüködést vizsgáljuk, ezért értékteremtő folyamatok menedzsment és humánerőforrás-menedzsment fókusszal vizsgáljuk az egyéni fejlesztéseket és karrierlehetőségeket. A kettős karrier a hivatásos pályára és a civil életre egyszerre készíti fel a sportolókat, ennek fontosságára az Európai Bizottság több tanulmánya és más szerzők is felhívták a figyelmet (Farkas et al., 2017 és Lupo et al., 2018). Kutatásunk során nagy hangsúlyt fektetünk arra, hogy a hazai labdarúgó vállalatok és akadémiák hogyan kezelik, fejlesztik legfőbb humán erőforrásukat, vagyis a jelenlegi és leendő hivatásos játékosokat. Szekunder kutatásunkat a hazai akadémiák felmérését végző nemzetközi vállalat (Double Pass) jelentésére alapoztuk, saját hozzájárulásunkat pedig a játékosok közvetlen megkérdezése jelentette, mely egyedülállónak tekinthető ebben a témában.

A 200 játékos megkérdezésével végzett kérdőíves kutatásunk eredményei egyrészt érdekesek a hivatásos játékosok karriermenedzsmentjével, illetve képzésével foglalkozó kutatók számára, másrészt pedig nemzetközi szinten is egyedinek tekinthetök, mert korábban nem végeztek a játékosok megkérdezésén alapuló kutatást a sportvállalatok értékteremtésére vonatkozóan. A tanulmány eredményei nemzetközi szinten is érdekesek lehetnek a sportmenedzsmenttel foglalkozók számára, mert a nagy mintán végzett vizsgálat segíti megérteni a játékosok képzésének hozzájárulását a labdarúgó vállalatok értékteremtéséhez. A gyakorlati oldal szereplői (Magyar Labdarúgó Szövetség, klubok, játékosügynökök) számára is relevánsak lehetnek eredményeink, mivel a hazai akadémiák müködését két éve az MLSZ megbízásából egy belga cég szakemberei értékelik, az audit során pedig nagy hangsúlyt fektetnek az üzleti müködésre és a játékosok képzésére. 


\section{Szakirodalmi áttekintés}

Kutatásunk megalapozásához áttekintettük a hivatásos labdarúgás, annak játékospiaca, valamint a játékosok fejlesztéséhez kapcsolódó hazai és nemzetközi szakirodalmat, illetve a játékosok és akadémiák körében végzett felmérések eredményeit.

Hivatásos sportvállalatok alatt a hivatásos klubokat, csapatokat müködtető vállalatokat értjük, amelyek a sport területén működve fogyasztói igényeket kívánnak kielégíteni nyereség elérése mellett (András 2003, 14; Núñez-Pomar et al., 2016). A sportban is azonosíthatóak az értékek (Chikán, 2008), amelyek olyan termékek vagy szolgáltatások, amelyek fogyasztói igényt elégítenek ki, ezért hajlandók értük fizetni. András (2003, p. 41.) alapján a legfőbb értékteremtő tényezőt a hivatásos labdarúgásban a megfelelő színvonalú sportteljesítmény jelenti. Egy klub értékteremtő tényezője lehet a játékosállománya, sztárjainak köre, futballjának stílusa, hiszen a labdarúgók az alapszolgáltatás minőségének letéteményesei (András 2003, p. 40.). A hivatásos klubok számára a játékosok közvetlen értékteremtést jelenthetnek a játékospiacon történő értékesítésük esetében, illetve közvetett hatással van a hivatásos sport többi piacára is: fogyasztói (Healy - McDonagh, 2013), szponzori (Herrmann et al., 2016), közvetítési jogok (Wolfe, 2002) és merchandise.

A hivatásos labdarúgás játékospiacán a csere tárgya a labdarúgó játékjog használatának átruházása. A piac szereplői a játékjog használatát átadó és átvevő futballvállalat, valamint a közvetítő játékosügynök, a magatartást befolyásoló legfőbb tényező pedig az átigazolási díj (András, 2004). Lejárt szerződés esetén a játékos maga rendelkezik játékjogának hasznosítási jogával, vagyis ez esetben ő számít eladónak. A hivatásos sport specialitása, hogy a munkavállalók (játékosok) igazolásával a sportvállalat nem csupán munkaszerződést köt, hanem vagyoni értékü jogként a játékos játékjogának használati joga is hozzá kerül (András, 2003). Tehát a játékos átigazolása nem csupán egy ,alkalmazott” felvételét, hanem komoly befektetési döntést is jelenthet (Carmichael, 2006).

Az értékteremtésnek a fentiekben ismertetett értelmezése (tulajdonosi és fogyasztói értékteremtés egy időben) mellett egy másik értelmezési lehetősége is megjelenik, mégpedig a reálfolyamatokon keresztül történő értékteremtés. „Az értékteremtő folyamat erőforrások beszerzése, kezelése és felhasználása abból a célból, hogy az ügyfeleknek értéket állítsunk elő" (Chikán 2008, p. 372.). A hivatásos labdarúgásban ez speciálisan jelenik meg, hiszen míg egy termelövállalatnál eszközök, munkaerő és információ felhasználásával az anyagból terméket és szolgáltatást állítanak elő, addig itt a játékosok nemcsak munkaerőként, hanem maguk is fejlesztendő erőforrásnak tekinthetők. A labdarúgó vállalatok esetében a játékosok fejlesztése a jövőbeli sportszakmai és pénzügyi eredményesség kulcsa. Ez esetben tehát speciálisan értelmezhető a vállalat erőforrásának a fogyasztói értékké konvertálása, hiszen egy élő ember képességeinek fejlesztésén keresztül javítható a sportvállalat szolgáltatásának színvonala, illetve növelhető a játékos játékjogának értéke is, amely- nek használati jogát a sportvállalat ellenérték fejében átruházhatja más sportvállalatra.

A vállalat sikerességét a reálfolyamatok megfelelö szervezése jelenti, különösen fontos a humánerőforrás-menedzsment, azon belül is a karriermenedzsment és a tehetséggondozás. A játékosok fejlesztésén keresztül javul a teljesítmény és így a tulajdonos és fogyasztói értékteremtés is megvalósulhat. A sportvállalatoknak tehát arra kell hangsúlyt fektetniük, hogy az infrastruktúra, a játékosok képzését támogató munkaerő, valamint az információ minél hatékonyabb kombinációjával a lehető legnagyobb mértékben fejlesszék játékosaikat, ezáltal járulva hozzá a vállalat értékteremtéséhez. Wolsey és szerzőtársai (2012, p. 159-160.) az egyéni és a csapatteljesítmény növelése érdekében javasolják többek közt a későbbi civil életre való felkészítést, karriertervezést a sportkarrier építése mellett. Brady és szerzőtársai (2008) tanulmányukban arra hívják fel a figyelmet, hogy a vezetésnek többek közt arra kell törekednie, hogy minden játékos és edző tisztában legyen a klub víziójával, stratégiájával és ezek elérését célzó részcélokkal, valamint saját szerepükkel. Ezen belül legyenek egyéni célkitűzések és rendszeres teljesítményértékelések.

A játékosokat a sportvállalatok kinevelhetik saját maguk (Chikán (2008, p. 181.) megfogalmazásában ,azokat a tevékenységeket, amelyeket a vállalat maga akar elvégezni, el kell helyezni a szervezetben: ki kell alakítani a megfelelő munkamegosztást és az ehhez kapcsolódó koordinációt"), vagy megvásárolhatják játékjogukat más sportvállalattól. „A vállalat a tranzakciós költségek mérlegelése útján jut el annak eldöntéséhez, hogy az igénykielégítéshez szükséges tevékenységek közül melyeket végezzen maga, s melyek elvégzését bízza külső partnerre" (Chikán, 2008, p. 180.). A hivatásos labdarúgásban a tevékenységek kiszervezése a „make or buy” dilemmában (Akgündüz - van den Berg, 2013) jelenik meg, amit magyarul leginkább a ,vásárlás, vagy nevelés” eldöntendő kérdésében fogalmazhatunk meg. Az utánpótlás-nevelés tulajdonképpen egy módszer a csapat legfőbb inputjának biztosítására. Akkor érdemes saját körbe bevonni alapvetően egy tevékenységet, ha a tranzakciós költségek ezt diktálják. A költségmegközelítésen túl az utánpótlás-játékosok csapatba építése függ a sportág sajátosságaitól (mennyire aktív a játékospiac, vagyis szükséges-e fizetni átigazolási díjat, vagy elegendő nagyobb fizetéssel átcsábítani játékosokat), a meglévő erőforrásoktól és infrastruktúrától is.

A nemzetközi szakirodalom alapján elmondható, hogy a hivatásos labdarúgásban kimutatható az összefüggés (nem lineáris) a játékosokra költött pénzösszeg (játékosvásárlás és fizetés), valamint a sportteljesítmény (egyéni és csapatszintü) között (Havran, 2016), így a minőségi játékosok iránti kereslet egyre jelentősebb forrásokhoz juttathatja a jó utánpótlás-mühelyekkel rendelkező klubokat, vagy azokat, amelyek megfelelöen tudnak kereskedni a játékosok játékjogaival. Utóbbira példa lehet a főleg dél-amerikai játékosok Európába csábításában élen járó portugál klubok, azonban a közép-európai bajnokságokra lényegesen kevesebb figyelem vetül, így 
az itt müködő kluboknak a játékosok kinevelése és értékesítése jelentheti a hosszú távú eredményesség alapját. A tehetséges sportolók kinevelését tekintik az állandóság alapjának cikkükben Kozma és Kazainé (2014, p. 13.) is. Egy sportvállalat legfontosabb tevékenysége a sportteljesítmény „kitermelésének” megszervezése. A sportteljesítmény „magában foglalja a sportolók fizikai, mentális és technikai képességeinek biztosítását. Ezenfelül aktív tevékenység szükségeltetik a játékospiacon, valamint az utánpótlás-nevelés rendszerének kialakítása" (Kozma Kazainé, 2014, p. 13.).

A játékospiac nemzetközi helyzetét vizsgálva megállapítható, hogy az UEFA (Európai Labdarúgó Szövetség) által szervezett kupákban indult klubok a bevételeik több mint 60\%-át fizetésekre, prémiumokra és hozzájuk kapcsolódó adókra költik. A személyi jellegű ráfordítások $79 \%$-át játékosokra költik, mindössze $21 \%$-a jut a technikai és adminisztratív személyzet költségeire (UEFA, 2013, p. 44.). 2009 és 2015 között 23,1\%-ról 19,7\%-ra csökkent az európai első osztályú bajnokságokban szereplő klubok kereteiben a saját nevelésü játékosok száma, vagyis egyre inkább a vásárolt játékosokra helyeződik a hangsúly, szabadabb a munkaerő áramlása, érzékelhetőbb a globalizáció hatása (CIES, 2015). A játékospiac nemzetköziesedését mutatja, hogy a hivatásos játékosokkal foglalkozó svájci kutatóintézet (CIES Football Observatory) 2015 július és október között csak 19 olyan klubot talált az európai első osztályú bajnokságokban, ahol a játszott percek arányát tekintve meghaladta az 50\%-ot a saját nevelésű játékosok aránya, ebből mindössze három volt Nyugat-Európában. A másik oldalról közelítve 32 klub egyáltalán nem nevezett saját nevelésü játékost egész évben a keretbe, 61 klub esetében pedig, ha voltak is a keretben, egyetlen percet sem játszottak (CIES, 2015, p. 6.). További kutatások is megerősítik, hogy az elmúlt években folyamatosan nőtt a nemzetköziesedés már a fiatal sportolók esetében is, egyre többen mennek egyre fiatalabban külföldre (CIES, 2016, p. 3.), valamint a kisebb bevétellel, lehetőséggel kecsegtető észak-európai és közép-európai bajnokságokból a fiatalok egyre hamarabb külföldre igazolnak, leginkább déli, vagy nyugat-európai bajnokságokba (CIES, 2016, p. 4.).

A CIES kutatói 2009 és 2015 között erős negatív korrelációt ( $\left.\mathrm{R}^{2}=41 \%\right)$ mutattak ki a bajnokságok UEFA-együtthatója (sportszakmai sikeressége) és a hazai fiatalok játékpercei között, tehát minél inkább támaszkodnak egy bajnokság klubjai a saját nevelésű fiatalokra, annál nehezebben érnek el jó nemzetközi sporteredményeket. Az átlagnál jobban teljesít (tehát sikeresebbnek mondható nemzetközi szinten a saját nevelésü játékosokkal) a német, a francia, a holland és a horvát bajnokság, amit a hatékony utánpótlás-nevelési rendszerüknek tulajdonítanak a szerzők. Másfelől átlag alatt teljesít a ciprusi, a lengyel, a bolgár és a magyar liga. A nemzetközi tanulmány külön kiemeli a gyenge magyar eredményt, a szerzők véleménye szerint erősen fejleszteni szükséges az utánpótlásképzést, az edzésmódszertant, valamint változtatni kell a fiatalok felé irányuló bizalmatlanságon (CIES, 2016, 7).

A régión belül más bajnokságokon végzett kutatások (András - Havran, 2016) is hasonló eredményre jutottak. Nemzetközi szinten is jegyzett sztárokat nem tudnak a közép-kelet-európai klubok megfizetni, illetve kinevelésük után nem tudják megtartani őket (Mihaylov, 2012). Továbbá, a játékosok értékesítése jelentheti számukra a gazdálkodás legfontosabb lábát, amelynek köszönhetően a hazai bajnokságban és nemzetközileg is versenyképesebbek lehetnek, de ez egyszerre korlátja is a jelentős nemzetközi elöre lépésnek (Roşca, 2012). A közép-kelet-európai régióban a játékosok értékesítéséhez kapcsolódó eredményt tekintve (a régió összesített teljesítménye 2010 és 2014 között meghaladta a 400 millió eurót) a magyar labdarúgás a leggyengébbek között szerepel. A vizsgált időszakban mindössze a realizált eredmény (az eladott játékosok után befolyt bevétel csökkentve a vásárolt játékosok vételárával) 2\%-át tették ki a magyar bajnokságból eladott játékosok, közülük is többen nem magyar nemzetiségüek voltak (András - Havran, 2014, p. 10.). Ezek alapján a játékosok felkészítésére és fejlesztésére való tudatos felkészülés és a transzferstratégia alkalmazása lehet a követendő út a hazai kluboknak. A transzferstratégia alkalmazása a klubok számára mind a sportszakmai, mind pedig a pénzügyi eredményesség fontos, de bevételeiket elsősorban a játékosok értékesítéséből szerzik. Ez esetben az utánpótlás-nevelés minősége jelenti a vállalat alapvető képességét (Szabados, 2003). Kutatásunk során az utánpótlás-nevelés és a játékosok fejlesztésének nem a sportszakmai hatékonyságát, hanem az azt kiegészítő, támogató funkciókat vizsgáltuk, amelyek a XXI. században elengedhetetlenek a nemzetközi játékospiacon való eredményes szerepléshez, illetve a labdarúgó-karriert követő civil életre való felkészüléshez. A nemzetközileg is kiemelkedő klubok akadémiáinak tapasztalatai szerint ilyen képzéseknek tekinthetők többek közt az idegen nyelvi, kommunikációs, informatikai, vagy pénzügyi képzések (ECA, 2015).

A kutatást egy előzetes, szekunder kutatás alapozta meg, amely során feltártuk a hazai játékosok fejlesztéséhez kapcsolódóan megjelent tanulmányok föbb megállapításait. Kifejezetten a sportszakmai vonatkozáson túlmutató, üzleti és képzési szempontokat vizsgáltuk. Ehhez egyrészt segítségünkre volt a Hivatásos Labdarúgók Szervezetének (HLSZ) kutatási jelentése ${ }^{1}$ a labdarúgóvá válást befolyásoló magyarországi körülményekről (HLSZ, 2014), másrészt pedig a Magyar Labdarúgó Szövetség (MLSZ) összefoglaló jelentése a belga Double Pass vállalat által készített akadémiai auditról (MLSZ, 2014). Az MLSZ a belga Double Pass vállalatot bízta meg az akadémiák, utánpótlás-központot minősítésével, a fejlesztésükre vonatkozó irányelvek és értékelési keretek kidolgozásával, ami azért különösen fontos, mert ez a vállalat dolgozta ki az elmúlt évtizedben kiemelkedő szakmai eredményeket elérő német labdarúgás utánpótlás-képzésének teljesítményértékelési és szervezési kereteit is. A tanulmányok szisztematikus átnézése után azonosítottuk a kiemelt kérdésköröket, amelyek alapján elvégeztük primer kutatásunkat. Az öt kutatási kérdéskör közül jelen tanulmányunkban az első három téma eredményeit ismertetjük. 
1. Tanulmányok (iskolarendszer, civil karrierre készülés, edzők és támogató személyzet felkészültsége hosszú távú oktatási tevékenységek),

2. Képzések (sportolói karrierlehetőségek javítása érdekében: nyelv, IT, kommunikáció stb. - hivatásos játékra való felkészítés),

3. Karrierlehetőségek és karriertámogatás (várakozások és realitások, játékospiac ismerete, önismeret, segítséget kitől kaphat),

4. Öngondoskodás,

5. Stratégia.

\section{Kutatási kérdés és módszertan}

Az előzetes tanulmányok átnézése alapján határoztuk meg, illetve pontosítottuk kutatási kérdésünket és hipotéziseinket, amelyeket kérdőíves módszertannal vizsgáltunk. Kutatási kérdésünk: Hogyan értékelhetö a hazai játékosok karriertámogatása és hivatásos pályára történő felkészültségük? Értékelésünk során a játékosok tapasztalataira, véleményére voltunk kíváncsiak, mert egyrészt a legfőbb érintettek (klubok, szövetség, ügynökök) válasza túl optimista lehet, másrészt ilyen kérdésekkel még nem keresték meg korábban magukat a játékosokat. Értékelésünk alapját a fö kérdéskörökben a korábbi tanulmányokból azonosított fejlesztési lehetőségek és karriertámogatási módszerek jelentették. Ezek alapján a nemzetközi tanulmányokhoz hasonlóan kiemelten vizsgáltuk a karrier-központú fejlesztési lehetőségeket, úgymint idegen nyelvi, informatikai, kommunikációs, pénzügyi képzések, iskolai tanulmányok támogatása, civil életre való felkészítés. A hivatásos pályára történő felkészítés szerves részét kell, hogy képezze a nemzetközi lehetőségek realitásának, illetve az ahhoz szükséges munka mennyiségének és minőségének ismertetése a játékosokkal.

\section{H1 Hipotézis: A klubok és a szövetség nem adnak a külföldi karrierhez szükséges támogatást a játékosok egyéni fejlesztéséhez és karriermenedzsmentjéhez.}

\section{H2 Hipotézis: A hazai játékosok saját megítélése a jövőbeni karrierlehetőségekről optimistább, mint amit az elmúlt évek hazai és regionális tapasztalatai mutatnak}

Mind a klubok, mind a szövetség szempontjából fontos lenne az erős külföldi bajnokságba történő játékosértékesítés. Előbbiek közvetlen nyereséget realizálhatnának, utóbbi pedig felkészültebb játékosokat remélhetne a válogatott számára. Az előzetes kutatásaink során azonosított képzések elérhetőségét vizsgáltuk az első hipotézishez kapcsolódóan, a második esetében pedig a valós átigazolási eredményekhez (András - Havran, 2014, 2016) viszonyítottuk a hazai játékosok várakozásait. A nemzetközi vállalatgazdaságtan kutatásai felhívják a figyelmet az expatrióták megfelelő felkészítésére a külföldi karrierhez kapcsolódóan (Kozma in Czakó - Reszegi, 2010). A hivatásos labdarúgásban még gyorsabban szükséges a beilleszkedés egy teljesen új környezetben, ezért fontos a játékosok erre való felkészítése. Mindkét hipotézis teszteléséhez saját szerkesztésü, anonim kérdőíves felmérést használtunk, amelynek során 200 hivatásos játékos, vagy hivatásos pályára készülő akadémista töltötte ki kérdőívünket ${ }^{2}$. A kérdések kialakítását az előzetes kutatásaink során azonosított öt területből négy vonatkozásában alakítottuk ki (a stratégiai témát a játékosoktól nem volt indokolt kérdezni), illetve három kérdést a HLSZ kérésére építettünk be. A kérdöív korlátja volt, hogy a kitöltések várható magasabb száma érdekében két A4-es oldalt nem haladhatott meg a terjedelme. A lehetséges módszerek közül az önkitöltős formát választottuk. Az önkitöltős forma előnye, hogy olcsó és gyors, hátránya, hogy a megkérdezettek hagynak ki kérdéseket (esetünkben átlagosan kevesebb, mint 5\%-a maradt a válaszoknak üresen, tehát nem okozott problémát) és nem alkalmas bonyolultabb problémák, összetett kérdések megválaszolására. A kérdőíveket a csapatkapitányok közremüködésével, csapatonként kapták meg a játékosok, a HLSZ volt segítségünkre a kérdőívek kiküldésében és visszagyüjtésében. Fontos szempont volt, hogy a hivatásos játékosok eléréséhez bizalmi viszony is szükséges, ezt biztosította a HLSZ részvétele a munkában. Meg kell említeni a kérdőívek begyüjtési módjának hátrányát is, miszerint a csapatoknak kiküldött kérdőíveket vagy egyáltalán nem küldték vissza egy klubtól, vagy ha visszaküldték, onnan nagyobb elemszám is érkezhetett. A kérdőívek elején rövid magyarázatot, leírást adtunk a kutatás céljáról, illetve a HLSZ kapcsolattartói is röviden tájékoztatták a klubok képviselőit, játékosokat a kutatás céljáról.

A kérdőíveket a hazai első (11 darab) és másodosztályú (16 darab) kluboknak (valamint licencproblémák miatt kizárt, de a minőségi utánpótlás csapatokat megőrző (5 darab) kluboknak), illetve akadémiáknak, utánpótlás-központoknak (10 darab) juttattuk el. Minden hivatásos labdarúgót foglalkoztató szervezetet, illetve hivatásos labdarúgó-karrierre készülő fiatal játékost szerepeltető egyesületet megkerestünk, mindössze egyetlen NB1-es klub volt, amely már a kérdőívek átvételétől is elzárkózott. A 42 megkeresett szervezet közül összesen 16 klub, illetve szervezet küldött vissza kérdöíveket. (4 darab NB1-es, 8 darab NB2-es, 2 darab alacsonyabb osztályú, valamint 2 darab akadémia). A papíralapon beérkezett kérdőíveket azonosítószámmal láttuk el és elektronikus formában rögzítettük, majd adattisztítást végeztünk, amely után SPSS és Excel programok segítségével dolgoztuk fel az eredményeket. A 200 beérkező válasz alapján az egyes kutatási területekre vonatkozóan adunk leíró statisztikát és mutatunk korrelációs eredményeket. A kérdőívek szövegének egyeztetése, kiküldése, beérkezése és feldolgozása 2015. november és 2016. május között történt.

A kapott eredményeket a hasonló témában megjelent tanulmányok (HLSZ, 2014; MLSZ, 2014) eredményeivel együtt értelmeztük, így a kvalitatív kutatások vegyes használatával, illetve a kvalitatív felmérés kvantitatív elemzésével növeltük kutatásunk következtetéseinek érvényességét. A kutatás után jelent meg az MLSZ frissebb tanulmánya, amelyet szekunder forrásként szintén feldolgoztunk (MLSZ, 2016). A kutatás alapjául vett 
minta nem tekinthető reprezentatívnak, de a véletlen mintavétel szabályainak a kérdöív kiküldése megfelelt, mert a teljes populációnak kiküldésre került a kérdöív (egy kivételével minden hivatásos játékost foglalkoztató, vagy hivatásos pályára felkészítő szervezetnek megküldtük a kérdőívet). Ugyanakkor a kitöltésekre és a visszaküldésre vonatkozóan ez már nem mondható el, mert az nagyban függött a klubok és a csapatkapitányok hozzáállásától. Fenntartásokkal kell kezelni eredményeinket az általánosíthatóság szempontjából, de a minta nagysága és a kiküldés teljeskörüsége eredményeink elfogadhatósága mellett szólnak. A kérdőív jellegéből fakadóan (a klub támogatására, korrektségére több kérdés irányult) amennyiben a klub gátolta annak kitöltését a játékosok körében, feltételezhető, hogy a választ nem küldő klubok játékosainak körében még gyengébb eredményeket kaphattunk volna a játékosok fejlesztésének támogatására vonatkozóan. A kutatás megbízhatóságához kapcsolódóan elmondható, hogy a kérdőív nagyrészt feleletválasztós, illetve zárt kérdéseket tartalmazott, így mind a kitöltés, mind pedig a feldolgozás során egyértelmü helyzetet eredményezett. A kérdöív nem tartalmazott szubjektív, szöveges válaszokat, így az adatok feldolgozóinak személyes értelmezése nem ronthatta a kutatás megbízhatóságát.

\section{Eredmények}

A visszaérkezett 200 kérdöív mindegyike használható volt az elemzés során, még ha néhány esetben maradtak is üresen hagyott válaszok (az egyes eredményeknél ezért jelöljük az elemszámot). A kutatáshoz kapcsolódón bemutatjuk eredményeinket a játékosok jelenlegi helyzetéről (tanulmányok, életkor, nyelvtudás, civil karrier stb.), jövőbeli céljaikról (magyar bajnokság, nemzetközi karrier, válogatott), valamint a játékosok fejlesztéséröl, képzésükről.

A kérdöívet kitöltők átlagéletkora 19,11 év volt, tehát a fiatalok felé tolódott a kérdőívek kitöltése, ezért a tanulmányokkal kapcsolatban külön is vizsgáltuk a 20 év alatti labdarúgók válaszait. 20 éves, vagy annál fiatalabb kitöltőből 144 fö volt (72\%), 17,2 év átlagéletkorral. A posztokat tekintve a teljes mintában 36 csatár (18\%), 73 hátvéd (36,5\%), 20 kapus (10\%) és 66 középpályás (33\%) volt, öt fö $(2,5 \%)$ nem adott választ.

\section{Tanulmányok}

A kérdőív első kérdéscsoportja a játékosok tanulmányaira koncentrált (1. ábra). A legtöbb játékos középiskolai tanulmányokat folytat, ami következik is életkorukból, de felsőfokú tanulmányokat $(8,1 \%)$ és szakmunkásképzést $(4,5 \%)$ is jelöltek meg. A megkérdezettek 26,3\%-a nem folytatott tanulmányokat a kérdöív kitöltésének idején.

A jelenlegi végzettséget a kitöltők életkorával együtt érdemes vizsgálni, hiszen nagyon sok a fiatal kitöltő, akik életkoruknál fogva nem tarthatnak elörébb - a fentebb ismertetettek szerint még középiskolai tanulmányokat folytatnak. A 18 évnél fiatalabb játékosok közül mindöszsze 4 fö volt, aki szakmát tanult és 3 fö, aki nem folytat tanulmányokat, azonban 96\%-uk középiskolában tanul, vagyis az életkorának megfelelő képzésben részesül. A 20 év alatti játékosok eredményeit $(\mathrm{N}=144)$ külön vizsgálva az látszik, hogy jelenleg 7-en (5\%) felsőfokú intézményben tanulnak, 117-en (80\%) középiskolába járnak, 7-en (5\%) szakmát tanulnak, 1 fö nem válaszolt és mindössze 12-en $(8,5 \%)$ nem tanulnak. A fiatalok komoly tanulmányi tervekkel rendelkeznek: 90 -en $(62,5 \%)$ felsőfokú képzést, 32-en $(22 \%)$ érettségit, 13-an ( $9 \%$ ) szakmát szeretnének szerezni a 21 év alattiak közül (mindössze 8 fö (5,5\%) esetében nincs tanulmányi cél, 2 fó pedig nem válaszolt).

1. ábra

\section{A játékosok megoszlása a jelenlegi tanulmányaik szerint}

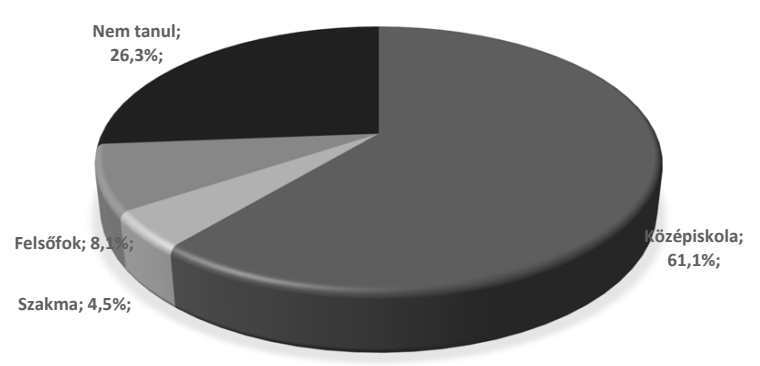

N=195, Forrás: saját felmérés

A teljes sokaságot tekintve a jövőbeli tanulmányi célok terén (2. ábra) pozitív kép rajzolódott ki, ugyanis legtöbbjük felsőfokú tanulmányokat tervez, ez nagyon komoly gondolkodásra utal. Természetesen a későbbiekben lehet, hogy sokan nem jutnak el a felsőoktatásba, de maga a tény, hogy célként gondolkoznak ezen, felelősségteljesnek mondható. A későbbiekben látni fogjuk, hogy sokan azért a labdarúgásban képzelik el jövőjüket, ami mellett nehéz lesz a felsőfokú képesítést megszerezni, de a későbbi civil életben, illetve a sikertelen játékoskarrier esetében ez is megvalósulhat.

2. ábra

\section{A tervezett végzettség megoszlása a játékosok körében}

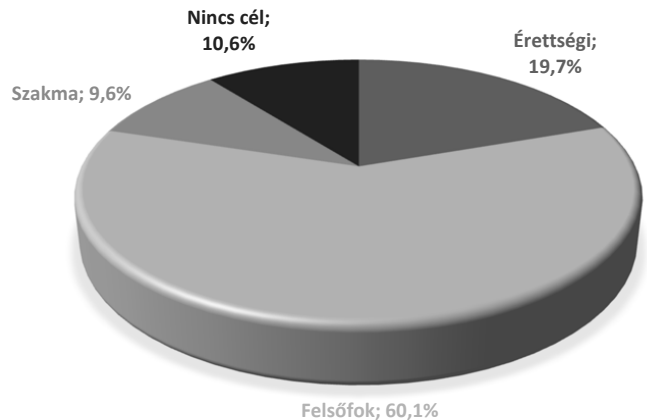

N=198, Forrás: saját felmérés

A végzettségeket tekintve a megkérdezettek 33\%-a rendelkezik érettségivel (22,7 év az átlagéletkoruk) és 3\%-a diplomával (29,75 év). Összességében 4,5\%-uk tanul szakmát (18,67 év az átlagéletkoruk), 60,5\%-uk jár középiskolába (16,81 év), 8\%-uk jár felsőfokú képzésre (21,4 év), 26\%- 
uk nem tanul jelenleg (24 év), illetve 2 esetben nem volt válasz.

A nyelvismeret kapcsán elmondható, hogy a legtöbbjük (90\%) beszél angolul legalább kezdő szinten (3.a ábra), a német nyelvtudást (3.b ábra) bármilyen szinten körülbelül a válaszadók fele jelölte meg. Legalább társalgási szinten angolul a megkérdezettek 54\%-a németül pedig 23\%-a tud (3. ábra). A 21 év alattiaknak mindössze $8,5 \%$-a nem beszél egyáltalán angolul.

\section{A játékosok megoszlása az angol (balra) és a német nyelvtudásuk alapján}

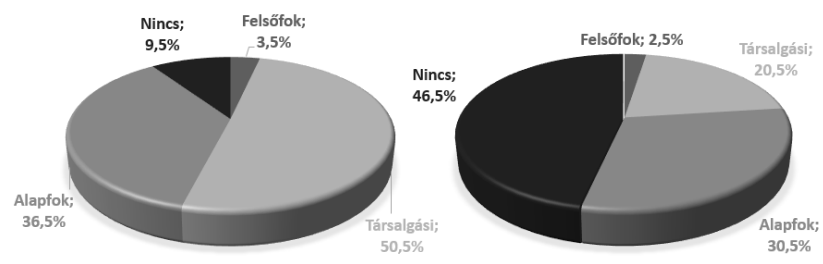

N=200, Forrás: saját felmérés

Angol és német nyelven kívül a játékosok 18\%-a jelölt meg más nyelvet, vagy nyelveket. Ezek közül a legtöbb említést a környező országok nyelvei kapták (13 - román, szerb, szlovák, ukrán - ők többségében határon túli magyarok lehetnek), illetve többen megjelölték még az olasz (10), a francia (7), illetve a spanyol (4) nyelvet. ${ }^{3}$

\section{Képzések és finanszírozásuk}

Ezen a témakörön belül arra fókuszáltunk, hogy a hazai játékosok milyen képzéseket javasolnának egy 16-20 év közötti játékosnak a labdarúgó-karrier előmozdítása érdekében.

\section{4. ábra}

A játékosok által fontosnak tartott tanfolyamok említése $(\%, \mathrm{~N}=200)$

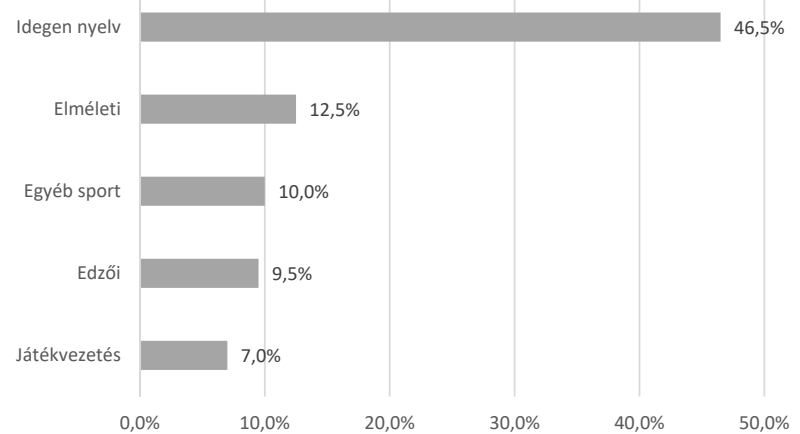

Forrás: saját felmérés

A 4. ábrán látható, hogy a játékosok egyaránt említettek sportszakmai és egyéb képzéseket is (nyitott kérdés volt). Sportszakmai képzések között speciális labdarúgó technikai képzést, vagy futsal oktatást említettek. Egyéb, elméleti képzések között pedig nem sporthoz kapcsolódó említések szerepelnek, úgymint pszichológia, pénzügyi ismeretek, életfilozófia, kommunikáció, informatika stb. A játékosok hasonló képzéseket soroltak fel, mint amit az előzetes vizsgálat során a tanulmányok is megjelöltek, jelentős volt az átfedés. Ezek után azt vizsgáltuk (feleletválasztós kérdéssel, de ők is megjelölhettek további képzést), hogy milyen tanfolyamokon vettek részt ténylegesen a megelőző két évben.

\section{A játékosok részvétele a fontosnak tartott tanfolyamokon $(\%, \mathrm{~N}=200)$}

5. ábra

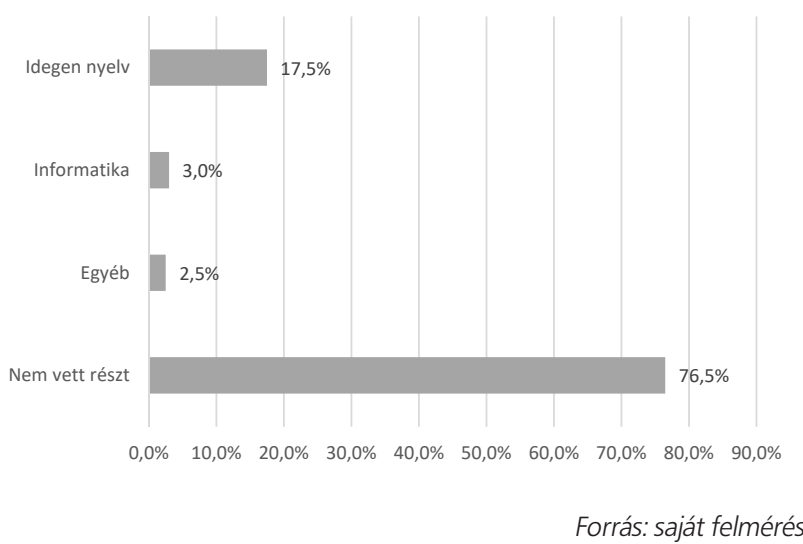

A szakmai előmenetelhez kapcsolódóan még 142-en (71\%) említettek legalább egy hasznos képzést (összesen 171 említés), de utána mindösszesen 46-an (23\%) vettek részt valamilyen képzésen (egy valaki kettőn is) (5. ábra). A képzések finanszírozásával kapcsolatban 85\%-uk azt jelölte meg, hogy saját maga, vagy családja finanszírozta azt. A 200 játékosból tehát mindössze 7 fönek (3,5\%) finanszirozott a karrierjéhez fontosnak tartott képzést a hazai labdarúgás legfontosabb érintettjeinek egyike (az MLSZ 2 fönek, a klubja 4 fönek, a játékosügynöke pedig 1 fönek). Ez az eredmény arra világít rá, hogy a hazai labdarúgás legfontosabb szereplői nem biztos, hogy rendelkeznek a játékosok képzéséhez kapcsolódó fontos ismeretekkel. Érdemes lenne tovább vizsgálni, hogy rendelkeznek-e cselekvési tervvel a hazai játékosok itthoni vagy külföldi karrierjének támogatásához kapcsolódóan.

\section{A labdarúgó-karrierhez kapcsolódó megállapítások}

A játékosok valamivel több, mint fele (105 fő a választ adó 189 fóből) nyilatkozott úgy, hogy jobban segítheti egy magyar játékos pályafutását, ha minél előbb külföldre igazol, mintha eltölt néhány évet a magyar bajnokságban. A játékosok közül 73 fő $(36,5 \%)$ a TOP5 bajnokság (angol, német, olasz, francia, spanyol) valamelyikét említette sportszakmai végső céljaként, illetve a holland, lengyel, osztrák első osztály és a német másodosztály is több szavazatot kapott. A játékosok több válaszlehetőséget is rögzíthettek, mert minél több, általuk is értékesnek, hasznosnak tartott bajnokságot szerettünk volna rögzíteni. Összességében a játékosok több, mint fele menne külföldre (40\% magyar 
első osztályt, 9\% magyar alsóbb osztályt jelölt meg végső célként), ami annak fényében érdekes, hogy a kérdőív másik kérdésére válaszolva sokkal kevesebb esélyt adtak a magyar fiataloknak külföldre jutni.

1. táblázat

A válaszadók szerint 100 fiatal hazai játékosból a megjelölt bajnokságokba kerülő játékosok száma

\begin{tabular}{l|c} 
Külföldi bajnokság & $\begin{array}{c}\text { Átlag } \\
\text { (fó) }\end{array}$ \\
\hline Angol, német, francia, spanyol, olasz 1. osztály & 4,78 \\
\hline Angol, német, francia, spanyol, olasz 2. osztály & 8,4 \\
\hline Portugál, holland, belga, svájci, orosz 1. osztály & 9,1 \\
\hline Lengyel, cseh, osztrák, szlovák, román 1. osztály & 14,2
\end{tabular}

Forrás: saját felmérés

A játékosok a legnagyobb esélyt a környező országok első osztályú bajnokságaiba való szereplésnek adták, ezt követte a portugál, holland, belga, svájci és orosz ligába történő bejutás esélye (1. táblázat). A TOP5 bajnokság első osztályába is 100 játékosból átlagosan 5-nek adnának esélyt, tehát a saját karrierlehetőségek mellett az átlagos magyar karrierlehetöségeket is felülbecslik. Örömteli vagy magas végső célokat tüznek ki maguk elé, de ha nincsenek tisztában a realitásokkal, a fokozatos és céltudatos fejlődés fontosságával, akkor torzulhat önképük. A fiatal hazai játékosok képzését úgy kell szervezni, hogy több lépcsőben érhessék el a legerősebb bajnokságokat, a közbenső bajnokságokat ugródeszkának használva. Egy speciális ellátási láncként értelmezhető ez, amelynek során a gyengébb magyar bajnokságból fokozatosan egyre erősebb bajnokságokba kerülhetnek. Magyarországon egyelőre nem tudják megadni a klubok és az akadémiák a játékosoknak azt a képzést, fejlesztést, amelynek köszönhetően olyan szintet érjenek el, amivel a TOP5 bajnokságba igazolhatnának közvetlenül.

6. ábra

Ugródeszkaként említett bajnokságok (\%, N=200)

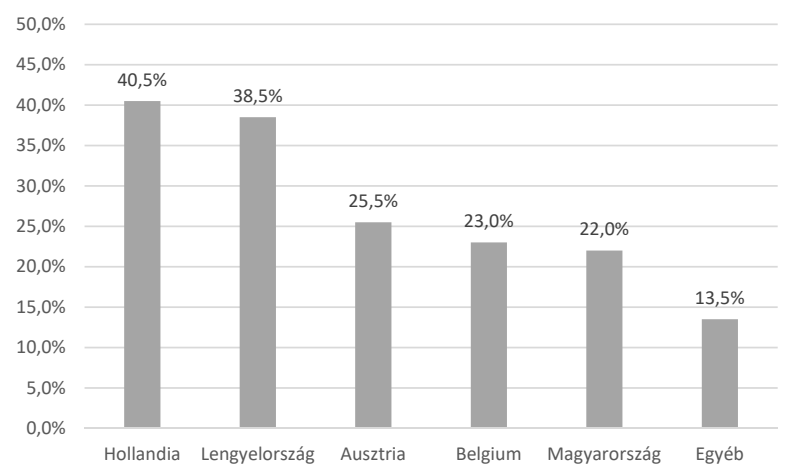

Forrás: saját felmérés

A válaszadók a TOP5 bajnokságba történő szerepléshez megfelelő ugródeszkának tekintették egy magyar játékos számára a holland és lengyel első osztályt, valamint sok válasz érkezett az osztrák, a belga és a magyar első osztályra is (6. ábra). A kérdés során nem adtunk meg előzetesen bajnokságokat, a kitöltők több bajnokságot is megjelölhettek.

Az eredményekből az látszik, hogy a korábbi évek tapasztalatai (hazai játékosok sikeres szereplése a holland és lengyel bajnokságokban) beépülnek a várakozásokba. Ezeket a bajnokságokat jobban figyelik a magyar bajnokságnál a nemzetközi megfigyelők és magasabb szintü játékot is várnak el, tehát valóban érdemes lehet a holland, belga, lengyel, osztrák bajnokság klubjaival felvenni a kapcsolatot egy hazai klub számára, ha hosszú távon szeretne játékoseladással bevételt elérni.

A kor és a karrierhez kapcsolódó változók között a következő, gyengének mondható, de szignifikáns kapcsolatokat találtuk:

1. minél idősebb volt a kitöltő, annál jobb lehetőségnek tartotta a belga $(r=0,242 ; \mathrm{p}=0,001)$, holland $(\mathrm{r}=0,248 ; \mathrm{p}=0,001)$, svájci $(\mathrm{r}=0,220 ; \mathrm{p}=0,002)$, lengyel $(r=0,191 ; p=0,008)$ első osztályba történő igazolást,

2. minél idősebb volt a válaszadó, annál kevésbé tartotta jó lehetőségnek az NB1-es bajnokságban eltöltött fiatal éveket ( $r=-0,211 ; p=0,003)$,

3. minél idősebb volt a kitöltő, 100 fiatal játékosból annál kevesebb esetében gondolta úgy, hogy TOP5 bajnokságba kerülhetnek $(\mathrm{r}=-0,187 ; \mathrm{p}=0,011)$.

Összességében tehát a tapasztalt játékosok a hazai bajnokság helyett a külföldi bajnokságot javasolják a fiataloknak és lényegesen realistábban ítélték meg a fiatal labdarúgók előtt álló külföldi karrierlehetőséget.

Külföldi karrier esetében a játékosok joggal várhatnak el magasabb fizetést a nagyobb teljesítményért cserébe. A 7. ábra mutatja egy lehetséges következő lépcsőfoknak tekinthető fizetési várakozásokat a német másodosztály, a holland első osztály és a lengyel első osztály választása esetén.

7. ábra

\section{Kereseti lehetőségekkel kapcsolatos várakozások}

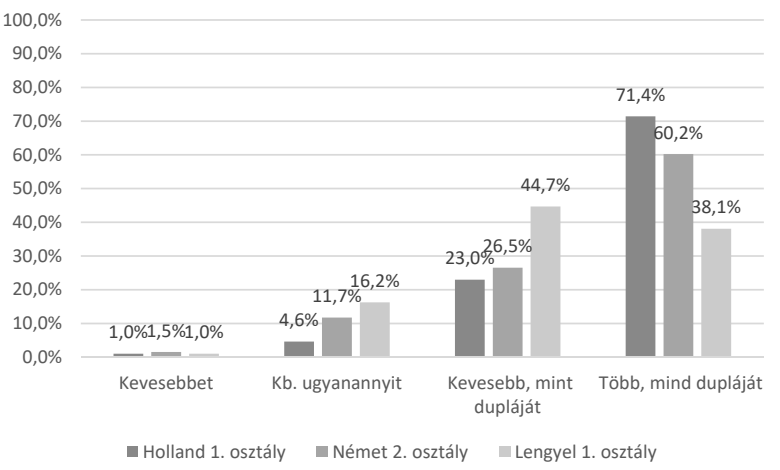

Forrás: saját felmérés

Mindhárom bajnokságban nagyobb fizetést vár a játékosok túlnyomó része. A magyar bajnokságnál kevesebb 
bért mindössze 1-2\%-a vár a játékosoknak ezekben a bajnokságokban, ugyanannyit 4,6\%-uk a holland első, $11,7 \%$-uk a német második és 16,2\%-uk a lengyel első osztályban. Összességében nagyobb bérre számítana a holland első osztályban a megkérdezett játékosok 94,4\%a, a német másodosztályban a $86,7 \%$-a, és a lengyel első osztályban 82,8\%-a. Jelentősebb fizetésbeli különbséget (több, mint a magyar dupláját) legtöbben $(71,4 \%)$ a holland első osztályban várnák, de még a német másodosztályban is a játékosok $60,2 \%$-a bízna ekkora keresetnövekedésben. A lengyel első osztállyal kapcsolatban óvatosabbak az elvárások, ott a játékosok 38,1\%-a jelölte meg, hogy a magyar bérek több, mint kétszeresét keresheti, míg 44,7\% szerint kevesebb, mint dupláját. Fontos, hogy a játékosok tisztában legyenek azzal, hogy külföldre igazolás esetén nehezebb a csapatba kerülni, de egyben könnyebb a nemzetközi piacot követő edzők, játékosügynökök, scout-ok figyelmét felkelteni. Így az első években nem biztos, hogy a lényegesen magasabb fizetési igény kell, hogy első számú cél legyen. A magyar bajnokságban megjelenő, nem üzleti bevételeknek a kívántnál nagyobb mennyisége korlátozhatja a magyar labdarúgókat a külföldi karrierjük elindításában, köszönhetően az alacsonyabb színvonalú magyar bajnokságban kereshető magasabb bérnek.

Fontos, hogy a hivatásos labdarúgás számos szereplője, érintettje közül kire számíthat karrierjének támogatásával kapcsolatban egy labdarúgó. Több választ is megjelölhettek a kérdöívben, végső soron szinte minden játékos (95\%) megjelölte a családját, barátját, tehát fontos számukra a közeli hozzátartozók véleménye. A szakmai vonalból a csapattárs és az edző kapta a legtöbb említést, előbbivel kapcsolatban 44\%-uk, utóbbiról pedig 39,5\%-uk gondolta úgy, hogy vele meg tudja beszélni karrierlehetőségeit. A játékosügynökök 39, a klubok (és alkalmazottaik az edzőt leszámítva) 27 említést kaptak $(19,5 \%$, illetve 13,5\%). Ez alapján úgy tünik, hogy a játékosok nem kapnak megfelelő támogatást a karrierjükkel kapcsolatban sem a munkáltatójuktól, sem pedig a nemzetközi szerződésekben segítséget nyújtó játékosügynököktől sem.

A kérdőív kitért a labdarúgó-karrier utáni, civil karrierhez kapcsolódó segítségnyújtásra is. Itt is magasan a család és a barátok kapták a legtöbb említést (93,\%), utána a csapattársak (35\%) és az edzők szerepeltek (20,5\%). A klubokat mindössze a játékosok 14\%-a, a játékosügynököket pedig 9,5\%-a jelölte meg. A civil karrierre való felkészítés egy fiatal labdarúgó esetében komoly felelősség, hiszen egyrészt nem biztos, hogy hivatásos labdarúgó marad sokáig, másrészt ilyenkor alapozhatja meg a játékos pályafutása utáni évek lehetőségeit, például egy megfelelően választott felsőoktatási programmal vagy nyelvtanulással. A munkáltató klubok és a szerződéseket támogató játékosügynökök hasonlóan alacsony számú említést kaptak, mint a hivatásos karrierrel kapcsolatos kérdésre.

A kor és a civil élettel kapcsolatos várakozások között az alábbi gyenge, de szignifikáns kapcsolatokat találtuk:
1. azok a játékosok, akiknek csak üzleti jellegű tervei vannak a jövőben, a többiekétől magasabb átlagéletkorral rendelkeznek. $(r=0,284 ; p=0,000)$,

2. azok a játékosok, akiknek csak sportszakmai tervei vannak a hivatásos karrierjüket követően, szignifikánsan alacsonyabb átlagos életkorral rendelkeznek a többiekhez képest $(r=-0,143 ; p=0,049)$.

Összességében tehát az idősebb játékosok inkább a labdarúgástól való eltávolodásnak adtak nagyobb esélyt, és sokkal kisebb esélyeket láttak a sportban való elhelyezkedésre, mint a fiatalok. Ez fontos lehet a fiatal labdarúgók számára, hiszen amellett, hogy sokkal optimistábban látják karrierlehetőségeiket a valóságnál, még a civil karrierjüket is a labdarúgásra építenék. Ugyanakkor előremutató, hogy a fiatal labdarúgók egyre nagyobb számban végeznek magasabb szintű oktatást, vagy terveznek felsőfokú tanulmányok elvégzésével.

Eredményeinket erősíti a kutatás után nyilvánosságra hozott MLSZ jelentés (MLSZ, 2016), amely a 2014-es audit folytatásának tekinthető. A kutatásunkhoz kapcsolódó főbb megállapításokat gyüjtöttük össze a 2. táblázatban, amely alapján kijelenthető, hogy a hazai játékosok képzésével, illetve mind a hivatásos, mind pedig a civil életre való felkészítéssel kapcsolatban megerösítik az MLSZ eredményei a cikkben megfogalmazott következtetéseinket.

2. táblázat

Az MLSZ 2016-os akadémiai felmérésének néhány kiemelt megállapítása

\begin{tabular}{|c|c|c|}
\hline Téma & Állítás & $\begin{array}{c}\text { Oldal- } \\
\text { szám }\end{array}$ \\
\hline Értékelés & $\begin{array}{l}\text { „Az egyéni (teljesítmény)értékelés } \\
\text { és személyes fejlesztés komoly fej- } \\
\text { lesztési területként azonosítható be } \\
\text { az akadémiák számára. Sem konkrét, } \\
\text { mérhető teljesítményindikátorok, sem } \\
\text { egyéni karrierutak nem kerültek meg- } \\
\text { fogalmazásra, kidolgozásra.” }\end{array}$ & 101 \\
\hline Civil élet & $\begin{array}{l}\text { „A szociális és életvezetési progra- } \\
\text { mok fejlesztése jelenleg kezdeti stádi- } \\
\text { umban van.” }\end{array}$ & 58 \\
\hline Karrier & $\begin{array}{l}\text { „A részletes karriertervezés és a pro- } \\
\text { fesszionális környezetbe való haté- } \\
\text { kony integráció lépésekre lebontott } \\
\text { konkrét egyéni terveinek elkészítése } \\
\text { egyelőre nem létező/alkalmazott fo- } \\
\text { galmak.” }\end{array}$ & 85 \\
\hline Fejlesztés & $\begin{array}{l}\text { „A játékosok minél magasabb szintre } \\
\text { történő fejlesztése érdekében egyénre } \\
\text { szabott fejlesztési tervek, programok } \\
\text { meghatározása, alkalmazása és érté- } \\
\text { kelése indokolt.” }\end{array}$ & 155 \\
\hline
\end{tabular}

Forrás: MLSZ (2016) 


\section{Következtetések}

A 3. táblázatban összegeztük az elvégzett vizsgálatok főbb megállapításait, a kutatás elején meghatározott témák szerint.

3. táblázat

\section{A kutatás főbb eredményeinek összegzése}

\begin{tabular}{|c|c|c|}
\hline 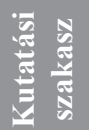 & Elözetes vizsgálat & Kérdoóves felmérés \\
\hline 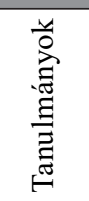 & $\begin{array}{l}\text { Alkalmazottak képzése és } \\
\text { értékelése esetleges } \\
\text { Oktatási és szociális } \\
\text { ügyekért felelős alkalma- } \\
\text { zott hiányzik }\end{array}$ & $\begin{array}{l}\text { Az akadémisták nagy } \\
\text { része tanul és továbbtanu- } \\
\text { lással tervez } \\
\text { Nyelvtanulás folyamatban }\end{array}$ \\
\hline 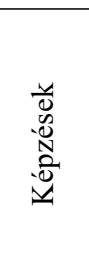 & $\begin{array}{l}\text { Egyéni képzés minimális } \\
\text { Pszichológusok száma } \\
\text { nagyon alacsony } \\
\text { Nyelvtanulás, IT, kom- } \\
\text { munikáció, életvitel, } \\
\text { személyiség fejlesztése } \\
\text { hiányos }\end{array}$ & $\begin{array}{l}\text { Idegen nyelv, IT, kommu- } \\
\text { nikáció képzéseket csak } \\
22 \% \text {-uk végez } \\
200 \text { föböl összesen } 7 \\
\text { főnek fizeti klub, MLSZ } \\
\text { vagy játékosügynök }\end{array}$ \\
\hline 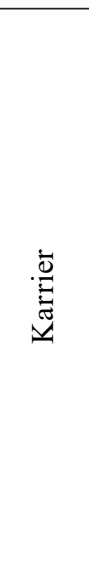 & $\begin{array}{l}\text { Táplálkozási tanácsadás, } \\
\text { prevenció nincs } \\
\text { Kevés orvos, masszőr, } \\
\text { egyéni edző } \\
\text { Tehetséggondozás ritka } \\
\text { Nem rendezett munkajogi } \\
\text { viszonyok }\end{array}$ & $\begin{array}{l}\text { Önértékelés torz, túlbe- } \\
\text { csülik saját karrierlehe- } \\
\text { tőségüket és általában a } \\
\text { magyar játékosok lehetö- } \\
\text { ségeit is } \\
\text { Külföldi fizetési elvárása- } \\
\text { ik túlzóak } \\
\text { Az indokoltnál kevesebb } \\
\text { támogatást kapnak a } \\
\text { klubtól, ügynöktől, szö- } \\
\text { vetségtől } \\
\text { Civil karrierre a klub, } \\
\text { szövetség, ügyök nem } \\
\text { készíti fel a játékosokat } \\
\text { Karrieralapot támogatnák }\end{array}$ \\
\hline
\end{tabular}

Forrás: saját szerkesztés

A felmérés eredményei szerint a kutatási kérdésünkre és hipotéziseinkre az alábbi válaszokat adjuk.

\section{H1 Hipotézis: A klubok és a szövetség nem adnak a külföldi karrierhez szükséges támogatást a játékosok egyéni fejlesztéséhez és karriermenedzsmentjéhez.}

A kérdőíves felmérés és a szekunder elemzés (tanulmányok áttekintése) eredményei alapján a H1 hipotézis elfogadható, tehát a hazai játékosok karriertámogatása és a hivatásos pályára való felkészitésük gyengének minösithető. A kérdőíves vizsgálat eredménye szerint a játékosok kevés egyéni képzést kapnak (az auditot végző vállalat nemzetközi viszonyítása alapján), klubjaik nem finanszírozzák a fejlődésüket segítő képzéseket (mindössze a játékosok 3,5\%-át támogatják így), és nem részesülnek megfelelö tehetséggondozásban sem. Primer kutatásunk eredményei alátámasztják a szekunder kutatásunk során azonosított problémákat, állításokat. A nemzetközi szinten elfogadott képzések, vagyis a klubok értékteremtő folyamatainak nem hatékony kialakítása miatt a hazai játékosok jelenlegi és jövőbeli teljesítménye elmarad a hasonló adottságokkal rendelkező regionális klubok játékosaihoz viszonyítva.

\section{H2 Hipotézis: A hazai játékosok saját megitélése a jövőbeni karrierlehetőségekről optimistább, mint amit az elmúlt évek hazai és regionális tapasztalatai mutatnak.}

A kérdőíves felmérés eredményei alapján a H2 hipotézis elfogadható, mert a játékosok a saját és a játékostársaik jövőbeli lehetőségeit is jobban látják a valós adatokhoz képest, ami az egyéni fejlesztésre vonatkozó motivációjukat is visszavetheti. Eredményeink szerint nem megfelelönek értékelhetö a fiatal magyar hivatásos labdarúgók felkészültsége a jövőjüket illetően. Tisztában vannak vele, hogy extra képzésekre lenne szükségük, de erre nem áldoznak energiát, időt, valamint ebben a klubjuktól, illetve a szövetségtől sem kapnak támogatást. Pozitívum, hogy a fiatalok tanulmányokat folytatnak, illetve terveznek is a jövőben végezni, valamint pozitív az MLSZ célkitűzése az akadémiák rendszeres átvilágítása és értékelése terén is. Az öngondoskodás terén szintén pozitív a játékosok hozzáállása, bár tájékozottságuk és klubjaik támogatása ebben is elmarad a kívánt szinttől.

Összességében tehát a hazai játékosok karriertámogatása és a hivatásos pályára történö felkészitésük Magyarországon még nem szerepel kellö súllyal a klubok és akadémiák stratégiájában, müködésében.

A hazai szövetség részéről megvan a cél az akadémiák auditálásán keresztül, de a klubok és akadémiák még nem müködnek úgy, hogy hatékonyan használják és fejlesszék immateriális eszközeiket a pályán és azon kívül, így egyrészt alacsonyabb játékszínvonalat, másrészt gyengébb kiegészítő tudást (nyelv, média, informatika, pénzügy) képviselnek a hazai labdarúgók. A játékosok képzéséhez, reális és tudatos karrierlehetőségek kialakításához a nemzetközileg alkalmazott módszereket minél nagyobb mértékben kell beépíteni a hazai labdarúgás műhelyeiben, a rendelkezésre álló források egy részét az ilyen jellegü képzések megszervezésére kellene fordítani. Továbbá javasoljuk a játékosok rendszeres tájékoztatását a karriercéljuk megvalósításához elvégzendő munka minőségével és mennyiségével kapcsolatban, ebben nagy segítséget tudnának adni nemzetközi karriert befutó hazai és külföldi játékosok, valamint kiemelkedő játékosértékesítési adatokkal rendelkező regionális klubok (föleg a horvát, szerb, lengyel és cseh bajnokságból).

\section{Jegyzet}

${ }^{1}$ A HLSZ a hivatásos játékosok nemzetközi érdekvédelmi szervezetének (FIFPRO) hazai képviselöjeként célul tüzte ki a hazai hivatásos labdarúgók magas szintü érdekvédelmének ellátását. A szervezet aktív kapcsolatban van a hazai hivatásos játékosokkal, akik segítségével már több alkalommal végeztek anonim felmérést. Legutóbbi felmérésüket 2014 tavaszán publikálták (HLSZ, 2014), abban a labdarúgóvá válást befolyásoló magyarországi körülményeket vizsgálták, ennek eredményeire is építünk kutatásunkban. 
${ }^{2}$ A kérdőívhez nyújtott ötletekért, szempontokért, javaslatokért köszönettel tartozunk Horváth Gábornak, Köves Alexandrának, Patkós Veronikának és Szabó Ágnesnek.

3 A kérdőív önkitöltős formája és piaci szakértők véleménye szerint érdemes fenntartásokkal kezelni a játékosok által megadott nyelvtudás valódi szintjét és használhatóságát.

${ }^{4}$ Megjegyzendő, hogy míg a szövetséggel és saját klubjával minden labdarúgónak van kapcsolata, játékosügynökkel (főleg a fiatalabbak) egy része nem rendelkezik, így őket nem is jelölhették meg itt. A kérdőív nem tért ki arra, hogy ki áll szerződésben játékosügynökkel.

\section{Felhasznált irodalom}

Akgündüz, Y. E. - van den Berg, M. R. (2013): Make or buy? Human capital accumulation strategies in European club football. Discussion Paper Series. Tjalling C. Koopmans Research Institute, 13(17)

András K. (2004): A hivatásos sport piacai. Vezetéstudomány, XXXV., p. 40-57.

András K. (2003): Üzleti elemek a sportban, a labdarúgás példáján. Doktori disszertáció. Budapest: BKÁE, Gazdálkodástani PhD-program

András K. - Havran Zs. (2017): A közép-kelet-európai hivatásos labdarúgás aktuális üzleti trendjei. XIV. Országos Sporttudományi Kongresszus. Letöltés helye: http://mstt.hu/wp-content/uploads/MSTT Szemle_2017_02.pdf; Letöltés ideje: 2017. november 5. András, K. - Havran, Zs. (2016): Examination of Central and Eastern European Professional Football Clubs' Sport Success, Financial Position and Business Strategy in International Environment. In: Competitiveness of CEE Economies and Businesses. Springer International Publishing, p. 197-210. doi: 10.1007/978-3-319-39654-5_10

András, K. - Havran, Zs. (2014): Regional Export Efficiency in the Market of Football Players. Theory, Methodology, Practice, 10(2), 3.

Brady, C. - Bolchover, D. - Sturgess, B. (2008): Managing in the Talent Economy: the football model for business. California Management Review, 50(4), p. 54-73. DOI: $10.2307 / 41166456$

Carmichael, F. (2006): The player transfer system in soccer. In: Andreff, W. - Szymanski, S. (eds.). (2006): Handbook on the Economics of Sport. Cheltenham: Edward Elgar Publishing, p. 668-676.

Chikán A. (2008): Vállalatgazdaságtan. 4. kiadás. Budapest: AULA Kiadó

CIES Football Observatory (2015): Youth training in European football: a comparative analysis, Monthly Report Issue no. 9, 2015 november http://www. football-observatory.com/IMG/pdf/mr09_eng.pdf Letöltés ideje: 2016. január 29.

CIES Football Observatory (2016c): The fielding of young footballers in Europe. Monthly Report, Issue no. 13, 2016 március http://www.football-observatory.com/ IMG/sites/mr/mr13/en/ Letöltés ideje: 2016. április 21.

Czakó E. - Reszegi L. (2010): Nemzetközi vállalatgazdaságtan. International Business Economics). Budapest: Alinea Kiadó

European Club Association (ECA, 2012): Report on youth academies in Europe. Nyon, France Letöltés helye: http://www.ecaeurope.com/news/eca-publishes- report-on-youth-academies/ Letöltés ideje: 2016. november 15.

Farkas J. - Jókai M. - Kozsla T. (2017): A sportolói kettős karrier fejlesztési lehetőségeinek vizsgálata Magyarországon $=$ Chances of Dual Career Development in Sport in Hungary. Testnevelés, Sport, Tudomány, 2(1-2), p. 83-90. DOI: 10.21846/TST.2017.12.14

Havran Zs. (2016): A játékosvásárlás és az eredményesség kapcsolata a hivatásos labdarúgásban. Vezetéstudomány, 47 (6), p. 30-40.

Healy, J. C. - McDonagh, P. (2013): Consumer roles in brand culture and value co-creation in virtual communities. Journal of Business Research, 66(9), p. 1528-1540. https://doi.org/10.1016/j. jbusres.2012.09.014

HLSZ: Kutatási jelentés (2014): A labdarúgóvá válást befolyásoló magyarországi körülményekről a hivatásos labdarúgók szervezete által a magyar labdarúgók körében végzett kérdőíves felmérés értékelése alapján. Budapest, 2014 http://www.hlsz.hu/doks/hlsz labdarugova_valas_jelentes.pdf letöltés ideje: $201 \overline{5}$. július 11.

Kozma M. (2010): A nemzetközi emberierőforrásgazdálkodás. in: Czakó E. - Reszegi L. (2010): Nemzetközi vállalatgazdaságtan. (International Business Economics). Budapest: Alinea Kiadó

Kozma M. - Kazainé Ó. A. (2014): Üzleti teljesítménymérés a sportban, avagy miként segítheti a sportszervezetek vezetöit a Balanced Scorecard koncepció a stratégia szerinti müködésben. Mühelytanulmány. Budapest: Budapesti Corvinus Egyetem, Vállalatgazdaságtan Intézet

Lupo, C. - Brustio, P. R. - Valentic, E. - Kiendl, D. Wenzel, R. - Stockinger, W. - Chaudhuri, S. (2018): The use of Focus Group Interviews to define the perceived importance of competencies related to the entrepreneurship as starting point for a new career in European athletes: an AtLETyC study. Sport Sciences for Health, 14(1), p. 9-17. https://doi.org/10.1007/ s11332-017-0385-2

Magyar Labdarúgó Szövetség (2016): Double Pass Hungary Globális jelentés. http://www.mlsz.hu/ wp-content/uploads/2016/06/DP_glob\%C3\%A1lisjelent $\%$ C3\%A9s.pdf Letöltés ideje: 2016. június 25.

Magyar Labdarúgó Szövetség (2014): Összefoglaló jelentés a Double Pass által készített akadémiai auditról. Budapest http://www.mlsz.hu/wp-content/ uploads/2014/06/MLSZ-AUDIT_140616.pdf Letöltés ideje: 2015. szeptember 15.

Mihaylov, M. (2012): A Conjoint Analysis Regarding Influencing Factors of Attendance Demand for the Balkan Football League. Master thesis. Köln: Deutsche Sporthochschule. www. academia.edu/download/30964444/Mihaylov_ MasterThesis15.09.2012_A_Conjoint_analysis_ regarding_influencing_factors_of_attendance demand_for_the_Balkan_League.pd̄f Letöltés ideje: 2015. július 26 . 
Núñez-Pomar, J. - Prado-Gascó, V. - Sanz, V. A. Hervás, J. C. - Moreno, F. C. (2016): Does size matter? Entrepreneurial orientation and performance in Spanish sports firms. Journal of Business Research, 69(11), p. 5336-5341. https://doi.org/10.1016/j. jbusres.2016.04.134

Roşca, V. (2012): The Financial Contribution of International Footballer Trading to the Romanian Football League and to the National Economy. Theoretical and Applied Economics, Volume XIX (2012), No. 4(569), p. 145-166.

Szabados G. (2003): Labdarúgóklubok stratégiái. Vezetéstudomány, XXXIV. évf. 2003. 09., p. 32-43.

Szymanski, S. (2014): On the ball - European soccer's success can be credited, in part, to the liberalization of the players' market. But what will the future bring? Finance \& Development, March, 2014, p. 26-28.
UEFA (2014): Club Licensing Benchmarking Report Financial Year 2014. http://www.uefa. org/MultimediaFiles/Download/Tech/uefaorg/ General/02/29/65/84/2296584_DOWNLOAD.pdf 2015. november 15 .

Wolfe, R. - Meenaghan, T. - O'Sullivan, P. (2002): The sports network: insights into the shifting balance of power. Journal of Business Research, 55(7), p. 611-622. https://doi.org/10.1016/S01482963(00)00191-0

Wolsey, C. - Minten, S. - Abrams, J. (2011): Human resource management in the sport and leisure industry. London: Routledge

\section{További internetes források}

www.hlsz.hu; www.transfermarkt.de; www.uefa.com

\section{E SZÁMUNK SZERZŐI}

Ócsai András, PhD-hallgató, Budapesti Corvinus Egyetem; Dr. Csillag Sára, tudományos rektorhelyettes, egyetemi docens, tanszékvezető, Budapesti Gazdasági Egyetem; Dr. Csapi Vivien, egyetemi adjunktus, Pécsi Tudományegyetem; Csákné Dr. Filep Judit, egyetemi docens, Budapesti Gazdasági Egyetem; Dr. Kása Richárd, tudományos főmunkatárs, Budapesti Gazdasági Egyetem; Dr. Radácsi László, rektori tanácsadó, Budapesti Gazdasági Egyetem; Csontos Réka Sára, kutató, Budapesti Corvinus Egyetem; Dr. Szabó Zsolt Roland, kutatóközpont-vezető, egyetemi docens, Budapesti Corvinus Egyetem; Dr. Havran Zsolt, egyetemi adjunktus, Budapesti Corvinus Egyetem; Dr. András Krisztina, tanszékvezető egyetemi docens, Budapesti Corvinus Egyetem 